\title{
DEFINING AND CONCEPTUALIZING GEOCULTURAL SCIENTIFIC LITERACY
}

\author{
TETYANA BLYZNYUK
}

\begin{abstract}
The article offers detail analysis of the notion literacy from various perspectives; traces its evolution from the original understanding (the ability to read, write, and use arithmetic) up to the contemporary complex interpretation by numerous sources, encompassing the multiple meanings and scopes of unquestionably vital competencies. Besides, the author emphasizes the relevance of teaching/learning Geocultural scientific literacy as an education discipline in institutions of higher education in general and understanding its components in particular while preparing teachers for New Ukrainian School. The paper stresses that modern pedagogical education of Ukraine, is an integral component of the European educational space, aimed at forming a professional with firm scientific knowledge, ability to transmit it within the subjects of the academic process and is capable of active and effective livelihoods in a multinational and multicultural environment. Thus, solid knowledge of geocultural scientific literacy provides the perfect grounds for international cooperation in education sector, understanding uniqueness of relationships between the cultures, communities' members, natural environments, politics, history and other measurements. This knowledge serves the basis for studying many university disciplines.
\end{abstract}

Keywords: literacy, scientific literacy, geocultural scientific literacy, lifelong education, fundamental skills, education sector, future primary school teachers.

\section{INTRODUCTION}

Geocultural scientific literacy (GCSL) is not a completely new phenomenon in the scientific world. Some its aspects were thoroughly defined by eminent domestic and foreign scholars. Edwards T. (2007) dealt with the problems of constant culturalization and geocultural issue, Cajkler, W. and Wood, P. (2016) successfully studied pedagogic literacy in initial teacher education; John A. Moore (1995) recognized the importance of teaching/learning both cultural and scientific literacy at higher education institutions. Ukrainian scholars disclose the issues of crosscultural literacy of modern teachers in the methodological context. For example, Semikin M.( 2013) points to the necessity of extended investigating the mechanisms of pedagogical transmission of crosscultural knowledge in the educational and cultural scope, monitoring and the following theoretical and methodological analysis of students' level of mastering scientific knowledge, received due to the realization of interdisciplinary connections principles are proved [14]. 
However, its notion sometimes is misunderstood and what is worse even limited to some particular components by some domestic scholars. Thus, we find it relevant to thoroughly explain and interpret this issue.

Literacy is crucial in helping us understand the world we live in. From the time we wake up to the time we go to bed, we are constantly interacting with the world around us. Firstly, let us make clear understanding of the notion literacy. However, you will not find a single interpretation as different sources and researchers offer different points of view on its understanding. The meaning of literacy in the English Dictionary is predictable: this is the ability to read and write, and use arithmetic. Therefore, it seems that everybody has a good idea what literacy is. Nevertheless, together with traditional understanding there are other more important components of literacy, which today encompasses much more than that.

The original meaning of the English word literacy is different from its translations in some other languages. In English history, the word 'literate' mostly meant to be 'familiar with literature' or, more generally, 'well educated, learned'. Only since the late nineteenth century has it also come to refer to the abilities to read and write texts, while maintaining its broader meaning of being 'knowledgeable or educated in a particular field or fields'. Since the middle of the twentieth century, scholars have given much attention to explain the definition of literacy. Scientists in such fundamental disciplines as Psychology and Pedagogy, Economics, Linguistics, Sociology, Anthropology, Philosophy and History have engaged in continuous and, often, highly contested debate over the meaning and definition of the term literacy and how it is related to the deeper and wider notions of education and knowledge. Taking into account these arguments, including the numerous traditions, critiques and approaches to literacy, we attempt to understand literacy:

- as an autonomous set of skills;

- literacy as applied and practiced;

- literacy as a learning process;

- literacy as text.

These broad areas of investigation contain almost all theoretical understandings of literacy.

\section{RESUltS AND DisCUSSION}

\subsection{EVOLUTION OF THE TERM “LITERACY”}

Nowadays evident changes in society effect all spheres of economy from agriculture to healthcare and education. In "Education for All Global Monitoring Report" (2006) it is mentioned that "literacy is a key outcome of education; it is difficult to separate the right to literacy from the right to education or the benefits of literacy from those of education" [3]. The official home web page of Alberta Education (Alberta province, Canada) offers the following definition of literacy as the ability, confidence and willingness to engage with language to acquire, construct and communicate meaning in all aspects of daily living. Language here is explained as a socially and culturally constructed integral system of communication.

However, the contemporary meaning of the term has been expanded to the ability not only use languages, numbers, images, computers, but many other basic means to understand, communicate, gain important knowledge, and use the typical symbol systems of a certain culture.

Together with all the changes in society, numerous complex globalization processes and informatization of all spheres of economy, the concept of literacy is being expanded in many world countries to include skills to access knowledge through technology and to assess sophisticated contexts. The key to literacy is reading development, skills of being able to understand spoken words, decoding written words for deep understanding of some information. When these skills are acquired, the learner can gain complete language literacy. That is to be able to critically analyze printed information, write with accuracy and consistency, use text information for decisions making and solving problems, creating new contents and ideas. The inability to do so is called illiteracy. Numerous official documents, including the Persepolis and Hamburg Declarations, offer a wider detail interpretation of 
literacy beyond the skills of reading and writing. Literacy can include access to information on scientific and technical knowledge, to means of using the benefits of culture and media (Organization of American States, 1948; United Nations, 1995; UNHCHR, 1969). Literacy is also interpreted as a foundational, universal life skill.

Moreover, United Nations Education Scientific and Cultural Organization UNESCO looks farther ahead and defines literacy in a more complex way - "the ability to identify, understand, interpret, create, communicate and compute, using printed materials associated with varying contexts. Literacy involves a continuum of learning in enabling individuals to achieve their goals, to develop their knowledge and potential, and to participate fully in their community and wider society" [3].

At the same time UNESCO roundtable (2003) emphasizes the goal of universal literacy under the motto "Literacy as Freedom", "reflecting the evolution of the concept of literacy: beyond its simple notion as a set of technical skills of reading, writing and calculating. . . a plural notion encompassing the manifold meanings and dimensions of these undeniably vital competencies. Such a view, responding to recent economic, political and social transformations, including globalization, and the advancement of information and communication technologies, recognizes that there are many practices of literacy embedded in different cultural processes, personal circumstances and collective structures".

Institutions of higher education are constantly seeking techniques that encourage students to become more globalized in their perspectives. Universities' administrations and Ministries of education encourage students to participate in numerous international exchange programs. Emphasis on academic internationalization is one of the driving forces factors of higher education reform in Ukraine and in the world. In accordance with the Mobility Strategy of European Space of Higher Education Area 2012, countries are encouraged to develop and implement national strategies for internationalization and mobility [6].

The starting point for this process is generally considered to be globalization with supporting factors, such as: convergence of national systems of higher education, introduction of international education, formation of the model of life-long learning integrated into the global educational community.

Thus, an additional remarkable trend interprets literacy in relation to technology, civic engagement and lifelong learning, placing specific prominence on the potential of communication technologies to sustain and advance cultural and linguistic multiplicity.

\subsection{Determining GeOCUltural SCIENTIFIC Literacy}

Changes and development of information technologies in the world lead to multiplying of literacies. Actually nowadays, the word literacy is often used to mean being generally competent at / having a reasonable knowledge of something. Many researchers understand literacy from another, quite a different perspective, as knowledge that is related to a specified subject (for example, computer literacy - knowledge of how to use a computer; or cultural literacy - knowledge of the culture you live in, assessment literacy, etc.). For the las decade the following terms have appeared in scientific literature related to literacy:

$\checkmark$ Digital literacy / digital information literacy

$\checkmark$ Pedagogical literacy

$\checkmark$ Library literacy

$\checkmark$ Computer / information technology / electronic / electronic information literacy

$\checkmark$ Media literacy

$\checkmark$ Internet / web / network / hyper-literacy and more.

The notion scientific literacy has been used in the literature for more than four decades (Gallagher \& Harsch, 1997), although not always with the same meaning (Bybee, 1997). Many understand it as a simple term and its major advantage is that it sums up, at the school level, the intentions of science education. However, there are researchers who see scientific literacy aligned with 'knowing science', limited to the intellectual components expressed above, and this view is particularly prevalent on the 
internet (those researches devote a central role for the knowledge of science). This idea is strongly supported by science teachers today.

On the other hand, scientists who see scientific literacy referring to a society usefulness understand in in a wider context. They interpret this phenomenon as a requirement to be able to adapt to the challenges of a rapidly changing world. Such point of view recognizes the need for reasoning skills in a social context, and above all, this perspective states that scientific literacy is for all, having little to do with science teaching; the need of functionality as a citizen within a society (at home, at work, in the community), not purely at a knowledge level, but in making decisions and acting as a responsible person. Only the last, however, may be suggested as emphasizing socio-scientific decision making, where it is not the changes to the natural world alone that are the focus, but also the way of thinking.

Cultural literacy is a term suggested by E. D. Hirsch (2001), referring to the ability to understand and participate fluently in a given culture. "Cultural literacy is an analogy to literacy proper (the ability to read and write letters). A literate reader knows the object-language's alphabet, grammar, and a sufficient set of vocabulary; a culturally literate person knows a given culture's signs and symbols, including its language, particular dialectic, stories, entertainment, idioms, idiosyncrasies, and so on" [4].

Defining geo-literacy we attempt to mention it provides the tools that will enable communities not only to protect cultural resources and reduce conflicts or misunderstanding in education sector, but generally to improve the quality of life worldwide.

Thus, after studying a number of researches in cross-cultural interaction, we can definitely express a deep concern about the predominant lack or even complete absence of thorough geographic and cultural (geocultural) knowledge among most students of institutions of higher education of both their own native land and countries beyond it. Of course, this is not bare Geography and we do not aim to teach students geographic location and features of the world countries. Our goal is to throw the light upon geocultural understanding between people communicating in the contemporary world of globalization. Our concern about this issue is rather caused by the lack of geocultural comprehension in the scientific world and consequently, misunderstanding, barriers, boundaries, mistakes, errors, made by people in education.

After thorough analysis of a wide range of definitions and interpretations of literacy in world theory and practice, we will attempt to offer one more field of knowledge - geocultural scientific literacy with its structural components (Fig 1).

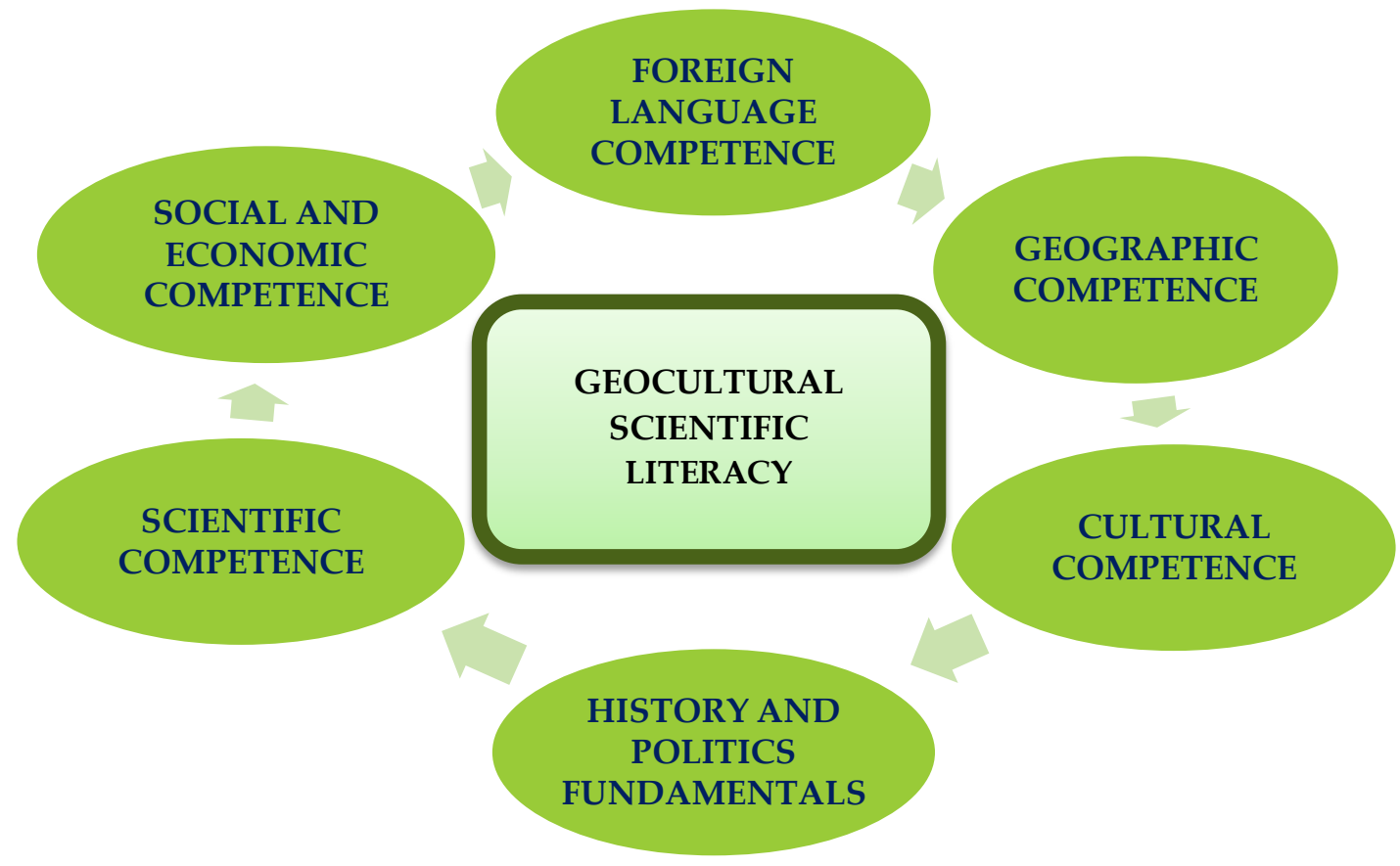

Fig. 1. Structure of geocultural scientific literacy. 
In our understanding, Geocultural scientific literacy implies the multisided competence of an individual's awareness of place, orientation, cultural understanding and ability to distinguish and critically evaluate spatial relationships in the international community for scientific decision-making, problem solving, developing one's own knowledge and potential, active participating in local and world community and general scientific lifelong education. It is built upon the most fundamental geographic, cultural, historic skills such as locating places, understanding the geocultural context of current events, developing a spatial perspective, thinking ability beyond one's own culture and learning to use innovative education approaches, geographic and scientific tools (maps, global information systems, active learning resources, apps, and so on).

We believe that GCSL as a university discipline might have important educational benefits for both students and the academic staff. The latter have enjoyed high level of professional independence and pedagogic freedom for now in relation to the development of the curriculum, choice of didactic material and responsibility for the direction of professional growth and development. However, since the beginning of the XXI century teacher's work has been characterized as 'qualification and quantification of value', a trend towards a 'marketization' culture in education. In our opinion, this phenomenon has two sides: positive and negative. Advantageous is the increase in raising standards of higher education. Teachers get more and more opportunities of their professional growth by visiting numerous trainings and exchange programs domestically and abroad.

Wide possibilities of geocultural scientific interaction within online education became another popular and efficient step for teachers' self-education where they can get professional knowledge provided by world famous universities. On the other hand, teachers feel constant pressure over what is going on in educational institutions and what teachers do in their classrooms; higher demands for teaching proficiency and readiness to fulfil wider professional responsibilities. Such an approach appears on a regular basis as a primary principle of educational reform in Ukraine.

Teacher standards are increasingly becoming a characteristic feature of national education systems. Thus, we strongly feel the necessity to put forward an alternative vision for understanding the 'professional growth' of teachers. Moreover, education must play a crucial role in defining and recognizing GCSL in order to single out educational problems and seek solutions. The individuals who deal with the issue and try to study it deeper or transmit knowledge to their students are in a unique position to be central to reforming the educational system in ways that will make it more effective. In the universities, teachers attempt to define and enhance the grounds of GCSL and educate those who will teach primary school children in modern classrooms, equipped according to the requirements of the New Ukrainian School, and who will become model citizens of Ukraine.

The educational content of GCSL will make it possible for students to become acquainted with geographical and cultural peculiarities of their native land and some English-speaking countries more profoundly. To accomplish this objective, students will be acquainted with innovative learning tools based on English-language educational electronic resources, which are already successfully and effectively practiced by their counterparts from the European leading institutions of higher education. As a result, the university graduates who will definitely become New Ukrainian school teachers can describe children how the world works and promote primary school children's readiness to have systemic understanding of the Motherland and foreign countries, geocultural reasoning skills, and systematic decision-making capability and other skills and competences which are crucial for our society.

\section{CONCLUSIONS}

Modern pedagogical education of Ukraine, as an integral component of the European educational space, is aimed to form a professional (Bachelor / Master) who has firm scientific knowledge, ability to transmit it within the subjects of the academic process and is capable of active and effective livelihoods in a multinational and multicultural environment. Future primary school teacher should have a developed sense of understanding and respect for other cultures and demonstrate it to the school 
children; be able to live in peace and harmony with the representatives of different nationalities, races, and beliefs. Such a teacher, being a citizen of Europe and adhering to universal human values, at the same time remains the unique bearer of own ethnic culture, able to provide students with the culture of different peoples living in one country and on one continent (Europe), creating the conditions for the emergence of a sense of trust and solidarity between them, ability to interact.

Thus, solid knowledge of geocultural scientific literacy provides the perfect grounds for international cooperation in education sector, understanding uniqueness of relationships between the cultures, communities' members, natural environments, politics, history and other measurements. This knowledge serves the basis for studying many university disciplines. International cooperation is currently being considered as one of the main indicators of the definition of quality in the field of education and science and, at the same time, one of the main tools for its maintenance and enhancement. Therefore, almost all institutions of higher education around the world are engaged in international activities and seek to expand them.

Taking into account the above mentioned data, we may conclude Geocultural Scientific Literacy an efficient study for all who intend to work in education sector as the main purpose of this study deals with getting students acquainted with cultural and geographical features of some countries, trends and prospects of international cooperation in the conditions of globalization.

\section{REFERENCES}

[1] Cajkler W., Wood P. Lesson Study and Pedagogic Literacy in Initial Teacher Education: Challenging Reductive Models. British Journal of Educational Studies, 64 (4) (2016), 503-521. doi: 10.1080/00071005.2016.1164295

[2] Edwards T. Geocultural literacy, part 1. Multilingual, \#90, 18 (6) (2007), 29-31. Available at: http://dig.multilingual.com/2007-09/

[3] Limage L.J. EFA Global Monitoring Report 2006: Literacy for Life by EFA Global Monitoring Report team at UNESCO:EFA Global Monitoring Report 2006: Literacy for Life. November 2006. Comparative Education Review, 50 (4) (2006), 711-714. doi: 10.1086/510055

[4] Hirsch E.D. Cultural Literacy: What Every American Needs to Know. Vintage Books, New York, 1988.

[5] Law of Ukraine "On Higher Education", 2014. Available at: https://zakon.help/law/1556-VII/ (in Ukrainian)

[6] Finikov T.V., Sharov O.I. (Eds.) Monitoring of the Integration of Ukrainian Higher Education System into European Higher Education and Research Area: Analytical Report. Takson, Kyiv, 2014. (in Ukrainian)

[7] Altbach Ph.G., Reisberg L., Rumbley L.E. Trends in Global Higher Education: Tracking an Academic Revolution. United Nations Educational, Scientific and Cultural Organization, Paris, 2009. Available at: https://unesdoc.unesco.org/ark:/48223/pf0000183219

[8] United Nations. Goal 4: Ensure inclusive and quality education for all and promote lifelong learning. Available at: http://www.un.org/sustainabledevelopment/education.

[9] Zhyliayev I.B., Kovtunets V.V., Syomkin M.V. Higher Education in Ukraine: State and Problems. Institute of Higher Education of NAPS of Ukraine, Kyiv, 2015. (in Ukrainian)

[10] Luis Fernandes. How to have an effective whole-school approach to digital tools in education? SchoolEducationGateway, 2016. Available at: https://www.schooleducationgateway.eu/en/pub/ viewpoints/experts/how_to_address_the_challenges_htm

[11] Recommendation of the European Union and of the Council of 18 December 2006 on key competences for lifelong learning (2006/962/EC). Official Journal of the European Union, (30/12/2006), L 394/10-L 394/18. Availaible at: http://eurlex.europa.eu/LexUriServ/LexUriServ.do?uri=OJ:L:2006:394:0010:0018:en:PDF

[12] Pahl K., Rowsell J. Literacy and Education: The new Literacy Studies and Teaching Literacy (Second edition). SAGE Publications Ltd, 2012. 
[13] Polistina K. Cultural literacy: Understanding and respect for the cultural aspects of sustainability. Available at: http://arts.brighton.ac.uk/_data/assets/pdf_file/0006/5982/Cultural-Literacy.pdf

[14] Semikin M.O. Crosscultural skillfulness of a modern teacher: methodological aspect. Scientific Bulletin Melitopol State Pedagogical University. Series: Pedagogy, 2 (11) (2013), 84-91. Available at: http://nbuv.gov.ua/UJRN/Nvmdpu_2013_2_12 (in Ukrainian)

[15] Smuschenko I.A. Cross-cultural literacy as an integral component of foreign language education of students of economic profile. Scientific Notes of Ostroh Academy National University: Philology Series, 42 (2014), 313-316. (in Ukrainian)

Address: Tetyana Blyznyuk, Vasyl Stefanyk Precarpathian National University, 57, Shevchenko Str., IvanoFrankivsk, 76018, Ukraine.

E-mail: blyztan@yahoo.com

Received: 21.01.2019; revised: 25.02.2019.

Близнюк Тетяна. Визначення і концептуалізація геокультурної наукової грамотності. Журнал Прикарпатського університету імені Василя Стефаника, 6 (1) (2019), 43-49.

У статті пропонується різносторонній аналіз поняття геокультурної наукової грамотності; починаючи від його традиційного розуміння (здатність читати, писати і використовувати арифметику) аж до сучасного багатокомпонентного виміру, який впливає на формування життєво важдивих компетентностей особистості. Крім того, автор підкреслює актуадьність вивчення геокультурної наукової грамотності як навчальної дисципліни у закладах вищої освіти, а також розуміння важдивості їі структурних складових під час підготовки вчителів Нової української школи. Підкреслюється, що сучасна педагогічна освіта України є невід'ємною складовою європейського освітнього простору і спрямована на формування фахівця 3 грунтовними науковими знаннями, умінням передавати їх у межах дисциплін освітнього процесу, здатного до активної та ефективної життедіяльності в багатонаціональному та мультикультурному середовищі. Таким чином, формування геокультурної наукової грамотності забезпечують міцну основу для міжнародного співробітництва в освітньому секторі, розуміння унікальності взаємовідносин між культурами, представниками різних громад, природним середовищем, політикою, історією та іншими вимірами. Ці знання слугують основою для вивчення багатьох університетських дисципдін.

Ключові слова: грамотність, наукова грамотність, геокультурна наукова грамотність, безперервна освіта, фундаментальні навички, освітній сектор, майбутні вчителі початкової школи.

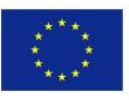

"The article has been prepared in the framework of the Erasmus+ project "MoPED - Modernization of Pedagogical Higher Education by Innovative Teaching Instruments", No. 586098-EPP-1-2017-1-UAEPPKA2-CBHE-JP. This project has been funded with support from the European Commission. This publication reflects the views only of the author, and the Commission cannot be held responsible for any use which may be made of the information contained therein". 